Reviu Akuntansi dan Bisnis Indonesia, Vol. 2 No. 1, Hlm: 92-96, Juli 2017

Website: http:/journal.umy.ac.id/index.php/rab

\title{
Pengaruh Komunikasi Dan Teknologi Informasi Terhadap Pemahaman Sumber Daya Manusia Dalam Penerapan Standar Akuntansi Pemerintah Berbasis Akrual Dengan Komitmen Organisasi Sebagai Variabel Intervening: Studi Empiris di SKPD dan Kecamatan Kab Sleman
}

Feraya Rosydiana; Barbara Gunawan

Program Studi Akuntansi Universitas Muhammadiyah Yogyakarta

I N F O A R T I K E L

\section{Kata Kunci:}

Pemahaman SDM, SAP

berbasis akrual,

Komunikasi, Teknologi

informasi, komitmen

organisasi.

Jenis Artikel:

Penelitian Empiris

Correspondence:

era@umy.ac.id

\begin{abstract}
A B S T R A K
Penelitian ini bertujuan untuk melihat pengaruh komunikasi, teknologi informasi, dan komitmen organisasi terhadap pemahaman SDM dalam penerapan SAP berbasis akrual. Penelitiani ini mengambil sampel pada pemerintahan kabupaten Sleman. Dimana di dalam LAKIP Sleman di cantumkan bahwa terdapat hambatan mengenai pemahaman. Penelitin ini menggunakan sample Jenuh di karenakan terbatasnya sample yang ada sehingga seluruh populasi dijadikan sample. Hasil penelitian menunjukkan bahwa Komunikasi dan teknologi informasi memiliki pengaruh terhadapa pemhaman SDM. Begitu pula dengan komitmen organisassi juga terbukti menjadi variable intervening dalam penelitian ini.
\end{abstract}

(C) 2019 RAB. Published by Universitas Muhammadiyah Yogyakarta

\section{PENDAHULUAN}

Banyaknya perubahan di era sekarang ini cukup berpengaruh pada setiap lini keorganisasian, kelembagaan, dan managerial demi mewujudkan permintaan laporan transparan masyarakat yang semakin meningkat dan akuntabel. Dengan adanya perubahan yang berdampak pada semua lini tersebut tentunya akan melibatkan masyarakat luas dalam penilaian program-program pemerintah untuk menjadikan kinerja pemerintah semakin meningkat.

Perubahan tersebut terjadi dari sisi sistem pemerintahan sektor publik yang sebelumnya dinilai kaku lalu berubah menjadi sistem pemerintahan yang mudah dipahami, di sesuaikan dan lebih flexibel. Perubahan-perubahan yang terjadi juga memaksa pemerintah untuk lebih menonjolkan sistem pemerintahan yang lebih baik lagi dan akuntable.

Pemerintah Indonesia telah melakukan perubahan pada sektor akuntansi. Salah satunya adalah pada sektor akuntansi pemerintah pusat dan pemerintah daerah, yaitu diwajibkannya menggunakan akuntansi basis akrual.

Akuntansi berbasis akrual juga dinilai lebih relevan menggambarkan keadaan keuangan sehingga cenderung menjadikan laporan keuangan pemerintah daerah lebih mudah diaudit dan pada kenyataanya laporan keuangan pemerintah daerah yang menggunakan akuntansi berbasis akrual lebih banyak mendapat opini wajar tanpa pengecualian. 


\section{TINJAUAN LITERATUR DAN PERUMUSAN HIPOTESIS}

\section{A. Teori Akuntabilitas}

Akuntabilitas (accountability) secara bahasa dapat diartikan sebagai pertanggungjawaban. Akuntabilitas publik adalah kewajiban pihak pemegang amanah (agent) untuk memberikan pertanggungjawaban, menyajikan, melaporkan, dan mengungkapkan segala aktivitas dan kegiatan yang menjadi tanggungjawabannya kepada pihak pemberi amanah (principal) yang memiliki hak dan kewenangan untuk meminta pertanggungjawaban.

\section{B. Teori Komunikasi}

Komunikasi yang baik merupakan hal yang sangat penting bagi efektivitas kelompok atau organisasi manapun. Persyaratan utama bagi komunikasi yang efektif adalah para pelaksana mengetahui apa yang mereka kerjakan, dalam hal ini menyangkut proses penyampaian informasi dan konsistensi informasi yang disampaikan yaitu pemahaman tentang SAP berbasis akrual.

\section{Teori Teknologi Informasi}

Teknologi informasi adalah istilah umum yang menjelaskan teknologi apapun yang membantu manusia dalam membuat, mengubah, menyimpan, dan mengkomunikasikan informasi (William dan Sawyer dalam Adventana;2014). Teknologi informasi meliputi komputer, pernagkat lunak (software),database, jaringan (internet, intranet),electronic commerce,dan jenis lainnya yang berhubungan dengan teknologi (Wilkinson et al., dalam Indriasari;2008).

\section{Komitman Organisasi}

Adventana (2014) komitmen organisasi adalah keadaan dimana pegawai mengaitkan dirinya ke organisasi tertentu dan sasarannya serta berharap mempertahankan keanggotaannya dalam organisasi itu.

\section{E. Sumber Daya Manusia}

Sumber Daya Manusia (SDM) mempunyai peranan yang sangat penting dalam pembangunan bangsa, sehingga untuk meningkatkan kualitas SDM diperlukan pendidikan. Dalam upaya mewujudkan bangsa dan masyarakat Indonesia yang maju, mandiri dan sejahtera, peranan pendidikan sangat penting. Pendidikan tinggi melalui kegiatan penelitian dan keilmuan dapat menghasilkan berbagai pemikiran dan konsepsi untuk memajukan harkat dan martabat manusia serta budaya bangsa melalui kegiatan pengembangan ilmu pengetahuan, teknologi dan karya seni yang bermutu sesuai dengan kebutuhan pembangunan.

\section{METODE PENELITIAN}

Jenis data yang digunakan dalam penelitian ini adalah data kuantitatif. Sumber data dalam penelitian ini adalah data primer, berupa data yang belum diolah yang diperoleh dari hasil kuisioner yang telah diisi oleh pegawai keuangan atau bagian akuntansi SKPD dan Kecamatan di Kabupaten Sleman yang terlibat dalam proses penyusunan laporan keuangan daerah.

\section{Metode Analisis Data}

\section{A. Uji Kualitas Data}


1. Uji Validitas

2. Uji Realibilitas

\section{B. Uji Asumsi Klasik}

1. Uji Normalitas

2. Uji Multikoloniaritas

3. Uji Heteroskesdastisitas

\section{Uji Hipotesis}

Analisis regresi linier berganda digunakan untuk menguji pengaruh antara Komunikasi dan Teknologi Informasi terhadap pemahaman SDM dalam penerapan SAP berbasis akrual dengan Komitmen Organisasi sebagai variabel intervening. Persamaan regresi linier berganda meliputi:

$$
\begin{gathered}
\mathrm{Y}=\alpha+\beta_{1} \mathrm{X}_{1}+\beta_{2} \mathrm{X}_{2}+\mathrm{e} \\
\mathrm{Z}=\boldsymbol{\alpha}+\boldsymbol{\beta}_{3} \mathrm{X}_{3}+\beta_{4} \mathrm{X}_{4}+\beta_{5} \mathrm{Y}_{1}+\mathrm{e}
\end{gathered}
$$

Keterangan:

$\mathrm{Z}=$ Tingkat pemahaman SDM dalam penerapan SAP berbasis akrual

$\mathrm{X} 1=$ Komunikasi

$\mathrm{X} 2=$ Teknologi Informasi

$\mathrm{Y}=$ Komitmen Organisasi

$\alpha=$ Konstanta

$\beta=$ Koefisiensi masing-masing variabel

$\mathrm{e}=$ Koefisien eror

\section{Uji F}

E. Uji T

F. Koefisien Determinasi

G. Path Analysis

\section{HASIL DAN PEMBAHASAN}

\begin{tabular}{|c|c|c|}
\hline Kode & Keterangan & Hasil \\
\hline $\mathbf{H}_{1}$ & Komunikasi berpengaruh positif terhadap komitmen organisasi & Diterima \\
\hline $\mathbf{H}_{2}$ & Teknologi informasi berpengaruh positif terhadap komitmen organisasi & Diterima \\
\hline $\mathbf{H}_{3}$ & $\begin{array}{l}\text { Komunikasi berpengaruh positif terhadap pemahaman SDM dalam penerapan SAP } \\
\text { berbasis akrual }\end{array}$ & Diterima \\
\hline $\mathbf{H}_{4}$ & $\begin{array}{l}\text { Teknologi Informasi berpengaruh positif terhadap pemahaman SDM dalam } \\
\text { penerapan SAP berbasis akrual }\end{array}$ & Diterima \\
\hline $\mathbf{H}_{5}$ & $\begin{array}{l}\text { Komitmen organisasi berpengaruh positif terhadap pemahaman SDM dalam } \\
\text { penerapan SAP berbasis akrual }\end{array}$ & Diterima \\
\hline $\mathbf{H}_{6}$ & $\begin{array}{l}\text { Komunikas berpengaruh positif terhadap pemahaman SDM dalam penerapan SAP } \\
\text { berbasis akrual melalui komitmen organisasi }\end{array}$ & Diterima \\
\hline $\mathbf{H}_{7}$ & $\begin{array}{l}\text { Teknologi Informasi berpengaruh positif terhadap pemahaman SDM dalam } \\
\text { penerapan SAP berbasis akrual melalui komitmen organisasi }\end{array}$ & Diterima \\
\hline
\end{tabular}

\section{Ringkasan Hasil Pengujian Hipotesis}




\section{KESIMPULAN}

Berdasarkan penelitian yang telah di lakukan, penulis menyarankan peneliti selanjutnya dapat menambahkan faktor-faktor lain yang juga dapat mempengaruhi pemahaman SDM dalam penerapan SAP berbasis akrual. Peneliti selanjutnya dapat mengganti lokasi penelitian, atau menambah lokassi penelitian, sehingga tidak hanya dalam satu kota saja, lalu dapat membandingkan antara satu kota dan kota lainnya tentang pemahaman SDM nya dalam menerapan SAP berbasis akrual. Penelitian selanjutnya dapat menambah instrument penelitian, sehingga tidak hanya menggunakan kuisioner,tetapi juga dapat memperoleh data dengan cara wawancara.

\section{DAFTAR PUSTAKA}

Adventana, G. A. (2014). Analisis Faktor-faktor yang Mempengaruhi Pemerintah Provinsi DIY dalam Implementasi SAP Berbasis Akrual Menurut PP No. 71 Tahun 2010, Artikel Publikasi, Universitas Atma Jaya, Yogyakarta

Akhyarudin, M. (2013). Tantangan Penerapan Akuntansi Berbasis Akrual Di Pemerintahan Indonesia. $\quad$ http://kaseiur.blogspot.com/2013/06/tantangan-penerapan-akuntansiberbasis.html (Diakses pada tanggal 12 April 2017)

Aldiani, S. (2009). Faktor-faktor pendukung keberhasilan penerapan peraturan pemerintah No.24 Tahun 2005 pada pemerintah Kabupaten Labuhan Batu. Jurnal Simposium Nasional XII, Universitas Sumatera Utara.

Ardiansyah. (2012). Faktor-faktor yang mempengaruhi kesiapan penerapan PP No.71 Tahun 2010 tentang Standar Akuntansi Pemerintahan (studi pada unit kerja KPPN Malang). Artikel publikasi, Universitas Brawijaya,Malang.

Ellyana, D. D., Achyar, R. \& Hamzah, A. (2009). Variabel Anteseden dan Konsekuensi Pemanfaatan Sistem Informasi (Studi Kasus pada Pemerintahan Kabupaten Madura). Jurnal Akuntansi dan Keuangan Indonesia, 6 (1), Juni 2009.

Faradilah, A. (2013). Analisis Kesiapan Pemerintah Daerah Dalam Menerapkan Standar Akuntansi Pemerintahan (Peraturan Pemerintah Nomor 71 Tahun 2010), Skripsi, Universitas Hasanuddin, Makassar.

Ghozali, I. (2006). Metode alternatf dengan partical last square, Semarang, badan penerbit UNDIP Hariyanto, A. (2012). Penggunaan Basis Akrual dalam Akuntansi Pemerintahan di Indonesia. STIE Dharma Putra , Semarang.

Herlina, H. (2013). Analisis Faktor-Faktor Yang Mempengaruhi Kesiapan Pemerintahan Daerah Dalam Implementasi PP 71 Tahun 2010 (Studi Empiris : Kabupaten Nias Selatan), Artike Pubikasi, Universitas Negri Padang.

Indah. (2008). Pengaruh Sumber Daya Manusia dan Teknologi informasinya terhadap Keberhasilan Penerapan PP No.24 tahun 2005, Artikel Pubikasi, Universitas Sumatera Utara, Sumatera Utara.

Indriasari, D. (2008). Pengaruh Kapasitas Sumber Daya Manusia, Pemanfaatan Teknologi Informasi dan Pengendalian Intern Akuntansi terhadap Nilai Informasi Pelaporan Keuangan Pemerintah Daerah (Studi pada Pemerintah Kota Palembang dan Kabuppaten Ogan Hilir), Simposium Nasional Akuntasi XI, Politeknik Negeri Sriwijaya, Palembang.

Katz, R. \& Tushman, M. L. (2003). A longitudinal study of the effects of boundary spanning supervision on turnover and promotion in research and deverlopement. Academy of Management Journal. 26(3), 437-456.

Kusuma, M. I. Y. (2013). Analisis Faktor-Faktor Yang Mempengaruhi Tingkat Penerapan Akuntansi Akrual Pada Pemerintah, Skripsi, Dipublikasikan, Universitas Diponegoro, Semarang

Laporan Akuntabilitas Kinerja Instansi Pemerintah, Inspektorat Kabupaten Sleman. (2015). Diambil dari http://inspektorat.slemankab.go.id/wp content/uploads/2016/09/LAKIPINSPEKTORAT-SLEMAN-2015.pdf, (Diakses pada tanggal 22 April 2017) 
Meyer, J. \& N. Allen. (1984). Testing the "side bet theory" of organizational commitment : Some methodological considerations. Journal of Applied Psychology, 69, 372-378

Nur. (2009). Teori Entitas. http://kolibri4info.blogspot.com/2009/05/teori-entitas-entity-theoryteori.html (Diakses pada tanggal 18 April 2017)

Pambajeng. (2015). Faktor-Faktor Yang Memengaruhi Penerapan Akuntansi Berbasis Akrual Di Pemerintah Daerah (Studi di Pemerintah Kabupaten Wonosobo), Universitas Muhammadiyah Yogyakarta

Peraturan Pemerintah Nomor 24 Tahun 2005 Tentang Sttandar Akuntansi Pemerintah Berbasis Akrual

Peraturan Pemerintah Nomor 71 Tahun 2010 Tentang Sttandar Akuntansi Pemerintah Berbasis Akrua

Porter, L. W. \& Steers, R. M. (1983). Motivation and work behavior, edisi 3, New York : McGrawHill

Putri, F. N. (2014). Analisis kesiapan dinas pendapatan propinsi jawa timur dalam menerapkan standar akuntansi berbasis akrual” Skripsi, Dipublikasikan, Universitas Airlangga, Surabaya.

Robbins, S. P., \& Judge, T. A. (2011). Perilku Organisasi. Terjemahan: Diana Angelica, Ria Cahyani, dan Abdul Rosyid. Jakarta: Salemba Empat

Romilia, R. (2011). Faktor-Faktor Yang Mempengaruhi Keberhasilan Penerapan Peraturan Pemerintah Nomor 24 Tahun 2005 Tentang Standar Akuntansi Pemerintah Di Kabupaten Bangkalan, Artikel Publikasi,Sekolah Tinggi Ilmu Ekonomi Perbanas, Surabaya.

Seminar Nasional, 19 Maret 2011, Audit Sektor Publik : "Peran SDM Aparatur Pemerintah Daerah dan Auditor Eksternal dalam Mendukung Keberhasilan Pelaksanaan Audit Keuangan Daerah”, www.umy.ac.id

Simanjuntak, B. (2010). Penerapan Akuntansi Berbasis Akrual di Sektor Pemerintahan di Indonesia. Disampaikan pada Kongres XI Ikatan Akuntan Indonesia, Jakarta.

Sumarsono, S. (2003). Ekonomi Manajemen Sumber Daya Manusia dan Ketenaga kerjaan, Jogyakarta, Graha Ilmu. 